\title{
Korelasi Feritin Serum dengan Neopterin Serum pada Penyandang Talasemia- $\beta$ Mayor Anak di Rumah Sakit Umum Pusat Dr. Hasan Sadikin
}

Idham Fadhillah, Susi Susanah, Dzulfikar D.L. Hakim

Departemen Ilmu Kesehatan Anak Fakultas Kedokteran Universitas Padjadjaran/RSUP Dr Hasan Sadikin, Bandung

Latar belakang. Penyandang talasemia- $\beta$ mayor berisiko lebih tinggi mengalami infeksi akibat disfungsi sistem imun karena kelebihan besi. Beban besi tubuh dapat ditunjukkan oleh kadar feritin serum (FS) sementara kadar neopterin serum (NS) merupakan penanda sensitif imunitas seluler tubuh.

Tujuan. Mengetahui korelasi kadar FS dengan NS pada penyandang talasemia- $\beta$ mayor anak.

Metode. Studi potong lintang dilakukan pada penyandang talasemia- $\beta$ mayor anak secara konsekutif yang telah mengalami kelebihan besi di Klinik Talasemia Anak RSUP Dr Hasan Sadikin pada Februari 2018. Subjek penelitian dipilih secara konsekutif. Kadar FS diperiksa dengan metoda immunoassay (CLIA), sedangkan NS dengan ELISA. Analisis statistik menggunakan korelasi rank Spearman, kemaknaan ditentukan berdasarkan nilai $\mathrm{p}<0,05$.

Hasil. Empat puluh anak memenuhi kriteria penelitian, terdiri dari 58\% laki-laki dan 48\% berusia lebih dari 10 tahun. Median kadar FS dan NS adalah 3391,1 ng/mL dan 0,57 nmol/L dengan rentang FS dan NS, yaitu 1038,1-7490,2 ng/mL dan 0,118-2,220 $\mathrm{nmol} / \mathrm{L}$. Secara keseluruhan korelasi kadar FS dengan NS diperoleh $\mathrm{r}=-0,474 ; \mathrm{p}=0,002$, sementara pada kadar FS $<2000 \mathrm{ng} / \mathrm{mL}$ didapatkan korelasi positif $(r=0,250)$.

Kesimpulan. Kadar neopterin serum berkorelasi dengan kadar feritin serum, FS tidak dapat digunakan untuk memprediksi status imun pada penyandang talasemia- $\beta$ mayor anak. Sari Pediatri 2018;20(2):85-9

Kata kunci: feritin, kelebihan besi, neopterin, talasemia- $\beta$ mayor

\section{Correlation of Serum Ferritin with Serum Neopterin in Children With $\beta$-Thalassemia Major in Hasan Sadikin General Hospital}

Idham Fadhillah, Susi Susanah, Dzulfikar D.L. Hakim

Background. Children with major $\beta$-thalassemia are at greater risk of infection due to immune system dysfunction caused by iron overload. Iron load can be demonstrated by measuring serum ferritin (SF) level while serum neopterin (SN) level is a sensitive marker of the body's cellular immunity.

Objective. To evaluate the correlation of SF with $S N$ in children with thalassemia- $\beta$ major.

Methods. A cross-sectional study was performed to children with iron overloaded-thalassemia- $\beta$ major who admits to Pediatric Thalassemia Clinic of Hasan Sadikin Hospital in February 2018, consecutively. The SF level was examined by immunoassay (CLIA) method, while SN by using ELISA. Statistical analysis using The Spearman Rank Correlation, the significance was determined based on the p-value $<0.05$.

Results. Forty children met the inclusion criteria of the study, consisting of $58 \%$ of male subjects and the age of $48 \%$ subjects were older than 10 years. The median levels of SF and SN were $3391.1 \mathrm{ng} / \mathrm{mL}$ and $0.57 \mathrm{nmol} / \mathrm{L}$ with a range of SF and SN 1038.1$7490.2 \mathrm{ng} / \mathrm{mL}$ and $0.118-2.220 \mathrm{nmol} / \mathrm{L}$, respectively. Correlation of SF with SN level was obtained $\mathrm{r}=0.474 ; \mathrm{p}=0.002 ;$ as higher the levels of SF the lower the SN level.

Conclusion. NS correlates with FS, but FS cannot serve as a predictive marker of the immune system in children with major $\beta$ thalassemia. Sari Pediatri 2018;20(2):85-9

Keywords: ferritin, iron overload, neopterin, thalassemia- $\beta$ major

Alamat korespondensi: Idham Fadhilah. Departemen Ilmu Kesehatan Anak Fakultas Kedokteran Universitas Padjadjaran, RSUP Dr Hasan Sadikin Bandung, Indonesia. JL. Pasteur no 38 Bandung 40151. Email: idhamfadhillah27@gmail.com 
$\mathrm{T}$ alasemia merupakan sekelompok kelainan genetik resesif autosomal yang menyebabkan defek pada sintesis rantai globin untuk pembentukan hemoglobin. Pada talasemia- $\beta$ mayor produksi rantai globin $\beta$ rendah atau tidak ada sehingga terjadi destruksi eritrosit prematur pada sumsum tulang (eritropoesis inefektif) yang mengakibatkan anemia dan memerlukan tata laksana transfusi darah reguler. ${ }^{1,2}$

Penyandang talasemia yang menjalani transfusi darah di Rumah Sakit Umum Pusat Dr. Hasan Sadikin (RSHS) pada tahun 2017 terdapat sekitar 700 orang dan sekitar 450 di antaranya merupakan anak-anak. ${ }^{3}$ Sebagian besar penyandang talasemia yang berobat ke Klinik Talasemia Anak RSHS adalah penyandang talasemia $\beta$ mayor. ${ }^{4}$

Pada penyandang talasemia $\beta$ mayor terjadi peningkatan penyerapan besi pada usus yang dapat mencapai 10 kali lipat dibandingkan pada anak normal. Setiap unit packed red cell (PRC) yang ditransfusikan mengandung sekitar $200 \mathrm{mg}$ besi dan tubuh tidak memiliki mekanisme efektif untuk mengekskresikan kelebihan besi. Dengan demikian penyandang talasemia- $\beta$ mayor berisiko mengalami kelebihan besi yang disebabkan oleh peningkatan absorpsi besi dan penambahan besi akibat transfusi darah berulang. ${ }^{5}$

Kelebihan besi menyebabkan gangguan aktivitas makrofag, gangguan fungsi neutrofil, penurunan aktivitas natural killer dan supresi fungsi sistem komplemen sehingga penyandang talasemia- $\beta$ mayor memiliki risiko lebih tinggi untuk mengalami infeksi akibat adanya disfungsi sistem imun. ${ }^{6}$ Infeksi merupakan penyebab kematian tertinggi kedua dan penyebab utama morbiditas pada penyandang talasemia- $\beta$ mayor. ${ }^{7,8}$

Tubuh tidak memiliki mekanisme yang efektif untuk mengekskresikan besi, satu-satunya metode yang dapat digunakan adalah penggunaan kelasi besi yang dapat mengeksresikan besi melalui urin dan atau feses. ${ }^{9}$ Besi yang tidak berikatan dengan protein dapat bereaksi dengan peroksida dan superoksida yang merupakan reactive oxygen species (ROS). Reaksi ini menghasilkan radikal hidroksil $(\mathrm{OH})$ yang sangat reaktif, bersifat merusak, dan menjadi penyebab utama inflamasi kronis. ${ }^{10}$ Paparan ROS terhadap sel limfosit $\mathrm{T}$ helper $1\left(T_{1}\right)$ menstimulasi produksi interferon- $\gamma$ (IFN- $\gamma$ ). IFN- $\gamma$ yang dihasilkan menstimulasi makrofag untuk memroduksi neopterin. ${ }^{11}$ Kadar besi berlebih menyebabkan terbentuknya ROS yang sangat reaktif yang berdampak pada peningkatan kadar neopterin dalam darah. ${ }^{8}$

Kelebihan besi tubuh diketahui melalui penilaian kadar feritin serum (FS). ${ }^{12}$ Neopterin merupakan penanda sensitif yang berkaitan dengan imunitas selular. ${ }^{13}$ Penelitian di Mesir pada tahun 2014 menunjukkan kadar neopterin yang meningkat secara bermakna pada penyandang talasemia- $\beta$ mayor bila dibandingkan dengan subjek sehat. ${ }^{14}$ Penelitian lainnya di Polandia pada tahun 2004 mendapatkan rerata median kadar neopterin serum pada subjek anak sehat adalah kurang dari $11 \mathrm{nmol} / \mathrm{L}$ dan tidak berkorelasi dengan usia. ${ }^{15}$

Tujuan penelitian ini untuk mengetahui korelasi kadar FS dengan NS dan mengetahui imunitas penyandang talasemia- $\beta$ mayor anak di RSHS.

\section{Metode}

Penelitian observasional analitik dengan rancangan penelitian potong lintang dilakukan pada penyandang talasemia- $\beta$ mayor anak yang berobat ke klinik Talasemia Anak RSHS pada bulan Februari 2018. Kriteria inklusi adalah penyandang talasemia- $\beta$ mayor, berusia kurang dari 18 tahun, FS lebih dari $1000 \mathrm{ng} / \mathrm{mL}$. Kriteria eksklusi adalah subjek yang secara klinis mengalami infeksi, menyandang human immunodeficiency virus (HIV) dan tuberkulosis (TB), telah dilakukan splenektomi.

Subjek penelitian diambil secara konsekutif sampai subjek minimum terpenuhi. Pemeriksaan FS diperiksa menggunakan metode chemilunescence immunoassay (CLIA), sementara NS menggunakan metode enzymed-linked immunosorbent assay (ELISA).

Analisis statistik menggunakan uji Pearson bila data berdistribusi normal dan Rank Spearman bila data berdistribusi abnormal untuk mengetahui korelasi kadar FS dengan NS. Analisis data dilakukan menggunakan statistical product and service solution (SPSS) for windows 21.0. Penelitian ini telah mendapat persetujuan Komite Etik Penelitian Kesehatan RSHS.

\section{Hasil}

Selama kurun waktu penelitian diperoleh 40 subjek. Subjek sebagian besar berusia di atas 10 tahun 
Tabel 1. Karakteristik subjek penelitian $(\mathrm{n}=40)$

\begin{tabular}{ll}
\hline Karakteristik & Jumlah \\
\hline Usia, (tahun), n & \\
$<5$ & 7 \\
$5-9$ & 14 \\
$\geq 10$ & 19 \\
Jenis kelamin, n & \\
Laki-laki & 23 \\
Perempuan & 17 \\
\hline
\end{tabular}

dan berjenis kelamin laki-laki (Tabel 1). Hasil uji normalitas data NS berdistribusi tidak normal sehingga analisis selanjutnya menggunakan korelasi rank Spearman (Tabel 2).

Kadar FS maupun NS pada subjek laki-laki dan perempuan tidak menunjukkan perbedaan bermakna $(\mathrm{p}>0,05)$. Sementara berdasarkan usia, kadar FS dan NS berbeda dan bermakna secara statistik $(\mathrm{p}<0,05)$ (Tabel 3).

Penelitian ini menunjukkan bahwa kadar FS dengan kadar NS berkorelasi negatif dan bermakna secara statistik $(r=-0,474, p=0,002)$, tetapi setelah dilakukan stratifikasi diperoleh korelasi positif pada kadar $\mathrm{FS}<2000 \mathrm{ng} / \mathrm{mL}(\mathrm{r}=0,25, \mathrm{p}=0,589)$. Usia

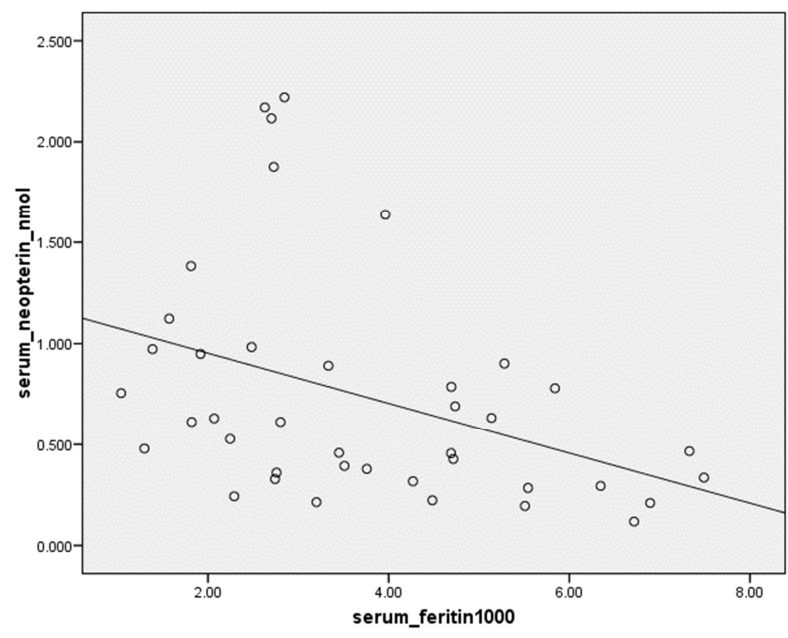

Gambar 1. Korelasi kadar feritin dengan neopterin serum

Tabel 2. Deskriptif statistik dari variabel yang diteliti

\begin{tabular}{lccccc}
\hline Variabel & \multicolumn{4}{c}{ Ukuran statistik } & Uji $\begin{array}{c}\text { normalitas data } \\
\text { (Nilai p*) }\end{array}$ \\
\cline { 2 - 5 } & Rerata & Standar deviasi & Median & Rentang & 0,074 \\
\hline FS (ng/mL) & 3750,43 & 1774,80 & 3391,10 & $1038,1-7490,2$ & 0,001 \\
NS (nmol/L) & 0,75 & 0,56 & 0,57 & $0,118-2,220$ & 0 \\
\hline
\end{tabular}

Keterangan: *Uji normalitas data dengan uji Shapiro-Wilk, nilai $\mathrm{p}>0,05$ data berdistribusi normal

Tabel 3. Perbedaan kadar feritin dan neopterin serum pada berbagai karakteristik

\begin{tabular}{|c|c|c|c|c|c|c|}
\hline \multirow[t]{2}{*}{ Karakteristik } & \multirow{2}{*}{$\begin{array}{c}\text { Feritin serum } \\
\text { Median }\end{array}$} & \multicolumn{2}{|l|}{ Nilai } & \multirow{2}{*}{$\begin{array}{c}\text { Neopterin serum } \\
\text { Median }\end{array}$} & \multicolumn{2}{|c|}{ Nilai } \\
\hline & & Rentang & $\mathrm{p}$ & & Rentang & $\mathrm{p}$ \\
\hline \multicolumn{7}{|l|}{ Usia (tahun) } \\
\hline$\leq 5$ & 1818,70 & $1038,10-4693,40$ & & 0,76 & $0,24-1,12$ & \\
\hline $5-9$ & 2786,70 & $1811,50-6894,70$ & $0,014^{*}$ & 0,92 & $0,21-2,22$ & $0,02^{*}$ \\
\hline$\geq 10$ & 4734,90 & $1295,60-7490,20$ & & 0,43 & $0,12-1,63$ & \\
\hline \multicolumn{7}{|l|}{ Jenis kelamin } \\
\hline Laki-laki & 3449,70 & $1295,60-7490,70$ & & 0,46 & $0,19-2,17$ & \\
\hline Perempuan & 2846,40 & $1038,10-7329,70$ & $0,914^{* *}$ & 0,63 & $0,12-2,22$ & $0,23^{* *}$ \\
\hline
\end{tabular}

Keterangan: " berdasarkan uji Kruskal-Wallis; ${ }^{* *}$ berdasarkan uji Mann-Whitney

Tabel 4. Korelasi antar variabel

\begin{tabular}{lcc}
\hline Korelasi & ${\text { Koefesien korelasi }(\mathrm{r})^{*}}^{*}$ & Nilai p \\
\hline Usia dengan kadar feritin & 0,450 & 0,004 \\
Usia dengan kadar neopterin & $-0,331$ & 0,037 \\
Feritin dengan neopterin & $-0,474$ & 0,002 \\
Feritin dengan neopterin (feritin serum $\leq 2000 \mathrm{ng} / \mathrm{mL})$ & 0,250 & 0,589 \\
\hline
\end{tabular}

Keterangan: berdasarkan korelasi Rank Spearman, bermakna bila $\mathrm{p}<0,05$ 
dengan kadar NS berkorelasi negatif dan bermakna secara statistik $(r=-0,331, p=0,037)$. Sementara itu usia dengan kadar FS berkorelasi positif dan bermakna secara statistik $(r=0,450, p=0,004)$ seperti tertera pada Tabel 4.

Secara lebih jelas korelasi antara kadar FS dan NS pada penelitian tertera pada Gambar 1 .

\section{Pembahasan}

Penyandang talasemia- $\beta$ mayor anak berisiko mengalami kelebihan besi yang disebabkan oleh peningkatan absorpsi besi dan transfusi darah berulang. Kadar FS berkorelasi dengan total cadangan besi dalam tubuh. ${ }^{15}$ Infeksi merupakan salah satu komplikasi utama yang terjadi pada penyandang talasemia mayor yang sudah mengalami kelebihan besi. Selain risiko paparan infeksi terkait transfusi darah berulang, diketahui pula bahwa penyandang talasemia mayor mudah terinfeksi karena adanya disfungsi imun. ${ }^{6}$

Kadar besi berlebih menyebabkan terbentuknya ROS yang berdampak pada peningkatan kadar neopterin dalam serum darah. ${ }^{10}$ Neopterin merupakan salah satu indikator imunitas selular. Peningkatan kadar NS menggambarkan difungsi imunitas. ${ }^{12}$

Hasil penelitian di Mesir tahun 2014 yang dilakukan terhadap 56 subjek penyandang talasemia- $\beta$ dan subjek sehat sebanyak 20 orang berusia 3-25 tahun menunjukkan median dan rentang NS penyandang talasemia- $\beta$ lebih tinggi dibandingkan pada subjek sehat. Median NS pada penyandang talasemia- $\beta$ adalah 19,0 nmol/L dengan rentang 10,0-33,0 nmol/L, sedangkan median NS pada subjek sehat adalah 9,0 $\mathrm{nmol} / \mathrm{L}$ dengan rentang $6,0-12,8 \mathrm{nmol} / \mathrm{L} .{ }^{13}$ Penelitian di Polandia yang bertujuan untuk mengetahui standar referensi kadar NS pada anak sehat dilakukan terhadap 105 subjek sehat pada Oktober 2004 hingga Juni 2005, terdiri dari 47 anak perempuan dan 58 anak laki-laki berusia 1 bulan-17,9 tahun melaporkan bahwa kadar NS rata-rata anak sehat setelah periode neonatus adalah kurang dari $11 \mathrm{nmol} / \mathrm{L}$. Kadar NS terendah pada penelitian tersebut adalah $2,87 \mathrm{nmol} / \mathrm{L}$ dan tertinggi $14,78 \mathrm{nmol} / \mathrm{L} .{ }^{14}$

Median kadar FS adalah 3391,1 ng/mL (rentang $1038,1-7490,2 \mathrm{ng} / \mathrm{mL}$ ), sementara median kadar NS adalah 0,57 $\mathrm{nmol} / \mathrm{L}$ (rentang 0,118-2,220 $\mathrm{nmol} / \mathrm{L}$ ). Hasil ini menunjukkan kadar NS lebih rendah dibandingkan penelitian sebelumnya. Hal tersebut mungkin berkaitan dengan perbedaan ras dan etnis subjek penelitian. Beberapa penelitian telah menunjukkan bahwa ras dan faktor lingkungan memengaruhi imunofenotipe limfosit seseorang. ${ }^{16}$ Neopterin merupakan salah satu penanda imunitas selular yang melibatkan limfosit $\mathrm{T}$, dan diproduksi oleh makrofag yang telah teraktivasi sebagai respons terhadap stimulasi IFN- $\gamma .{ }^{11}$

Berdasarkan usia, kadar FS dan kadar NS berbeda sehingga untuk keperluan analisis lebih lanjut, usia dijadikan sebagai variabel perancu. Korelasi usia dengan kadar NS berkorelasi negatif. Hal tersebut berbeda dengan penelitian sebelumnya yang melaporkan bahwa kadar neopterin tidak berkorelasi dengan usia. Namun, penelitian tersebut dilakukan pada subjek sehat. Usia dengan kadar FS berkorelasi positif, sedangkan kadar FS dengan kadar NS berkorelasi negatif tingkat sedang. Setelah dilakukan stratifikasi, korelasi positif antara FS dan NS didapatkan pada kadar FS $<2000 \mathrm{ng} / \mathrm{mL}$.

Korelasi negatif didapatkan antara FS dan NS pada kadar FS >2000 ng/mL. Laporan penelitian di Iran pada tahun 2007 disebutkan penyandang talasemia- $\beta$ dengan kadar feritin di atas $4.500 \mathrm{ng} / \mathrm{mL}$ mempunyai kadar IFN- $\gamma$ lebih rendah dibandingkan dengan kadar feritin kurang dari $4500 \mathrm{ng} / \mathrm{mL} .^{8}$

Neopterin dihasilkan oleh makrofag dan sel dendritik sebagai respons stimulasi IFN- $\gamma$. Produksi neopterin distimulasi juga oleh TNF- $\alpha$ dan liposakarida, tetapi IFN- $\gamma$ merupakan stimulan poten untuk menghasilkan neopterin. ${ }^{8}$ Kadar feritin yang tinggi dapat menyebabkan inhibisi aktivitas IFN- $\gamma$ dan makrofag kehilangan kemampuan untuk membunuh patogen intraselular serta penurunan aktivitas fagositosis oleh monosit, makrofag, dan leukosit polimorfnuklear. ${ }^{7}$

Penelitian tahun 2010 di Baltimore pada subjek dewasa dengan rentang usia 18-87 tahun dilaporkan bahwa neopterin dipengaruhi oleh usia, jenis kelamin, ras, indeks masa tubuh (IMT), dan persentase lemak tubuh. ${ }^{17}$

Keterbatasan penelitian ini adalah penilaian infeksi yang hanya secara klinis dan tidak dibantu oleh pemeriksaan penunjang, jumlah subjek setiap kelompok usia tidak merata, tidak meneliti pengaruh faktor lain seperti IMT dan persentase lemak tubuh serta tidak adanya standar NS pada subjek sehat yang mempunyai ras dan etnis yang sama dengan subjek penelitian. 


\section{Kesimpulan}

Hasil penelitian menunjukan kadar feritin dan neopterin serum berkorelasi negatif (tingkat sedang) sementara korelasi positif terjadi pada kadar FS $<2000$ $\mathrm{ng} / \mathrm{mL}$. Dengan demikian, FS tidak dapat digunakan untuk memprediksi imunitas penyandang talasemia- $\beta$ mayor anak di RSHS. Perlu dilakukan penelitian lebih lanjut untuk mengetahui kadar NS pada subjek sehat dan pada penyandang talasemia- $\beta$ mayor anak dengan jumlah subjek yang lebih besar dan melibatkan faktor memengaruhi lainnya.

\section{Daftar pustaka}

1. Fucharoen S, Winichagoon P. Haemoglobinopathies in Southeast Asia. Indian J Med Res 2011;134:498-506.

2. Galanello R, Origa R. Beta-thalassemia. Orphanet J Rare Dis 2010;5:11.

3. Data Klinik Thalassemia RSUP Dr. Hasan Sadikin. Bandung: Data klinik thalassemia; 2017.

4. Susanah S, Idjradinata P. Hubungan Tipe Thalassemia $\beta$ serta Polimorfisme c.-582 A>G Promotor Gen HAMP dan Status Besi thalassemia $\beta$ Berat Baru. Majalah Kedokt Bandung 2015;47:192-8.

5. Prabhu R, Prabhu V, Prabhu R. Iron overload in beta thalassemia-a review. J Biosci Tech 2009;1:20-31.

6. Ricerca BM, Girolamo AD, Rund D. Infections in thalassemia and hemoglobinopathies: focus on therapy-related complications. Mediterr J Hemat Infect Dis 2009; 1: e2009028.

7. Vento S, Cainelli F, Cesario F. Infections and thalassaemia. The Lancet Infecti Dis 2006;6:226-33.

8. Gharagozloo M, Karimi M, Amirghofran Z. Doublefaced cell-mediated immunity in $\beta$-thalassemia major: stimulated phenotype versus suppressed activity. Ann hematol
2009;88:21-7.

9. Kell DB. Iron behaving badly: inappropriate iron chelation as a major contributor to the aetiology of vascular and other progressive inflammatory and degenerative diseases. BMC Med Genomics 2009;2:2 doi: 10.1186/1755-8794-2-2.

10. Schroecksnadel K, Fischer B, Schennach H, Weiss G, Fuchs D. Antioxidants suppres Th1-type mmune response in vitro. Drug Metabolism Letters 2007;1:166-171

11. Williamson MA, Snyder LM. Wallach's interpretation of diagnostic tests. Edisi ke-9. Philadelphia: Wolters Kluwer Health/Lippincott William and Wilkins; 2012.

12. Akgul EO, Aydin I, Cayci T, Kurt YG, Aydin F, Agilli M. The indicator of cellular immune response in body fluids: neopterin. Gulhane Med J 2013;55:237-43.

13. Shanab A, El-Desouky M, Kholoussi N, El-Kamah G, Fahmi A. Evaluation of neopterin as a prognostic factor in patients with beta-thalassemia, in comparison with cytokines and immunoglobulins. Archives of Hellenic Medicine/Arheia Ellenikes Iatrikes 2015;32:60-5.

14. Porter J, Viprakasit V. Iron overload and chelation. Dalam: Cappelini MD, Cohen A, Porter J, Taher A, Viprakasit V, penyunting. Guidelines for the management of transfusion dependent thalassaemia. Edisi ke-3. Cyprus: Thalassaemia International Federation; 2014.

15. Nazar KP, Luczak G, Borkowska A, Galinska AD, Kozielska E, Marek K, dkk. Reference standard of serum neopterin concentration in healthy children. Pteridines 2007;18:19-24.

16. Senju M, Makiyama K, Hara K, Hulstaert F, Lowder JN, Jewell DP. Two-color immunofluorescence and flow cytometric analysis of peripheral blood lymphocyte subsets in caucasian and japanese healthy subjects. Jpn J Med 1991;30:509-15.

17. Spencer ME, Jain A, Matteini A, Beamer BA, Wang NY, Leng SX, dkk. Serum level of the immune activation marker neopterin change with age and gender and are modified by race, BMI, and percentage of body fat. J Gerontol A Biol Sci Med Sci 2010;65:858-8. 